Dunaetz, D. R., \& McGowan, J. (2019). Perceived strengths and weaknesses of American churches: A quadrant analysis of church-based ministries. Great Commission Research Journal, 10(2), 128-146.

\title{
Perceived Strengths and Weaknesses of American Churches: A Quadrant Analysis of Church-Based Ministries
}

\section{David R. Dunaetz}

Azusa Pacific University'

Joshua McGowan

Azusa Pacific University

\begin{abstract}
:
The needs and expectations of both Christians and non-Christians concerning churches vary according to the cultural context. Similarly, a church's ability to respond to these needs depends on its ability to fine-tune ministries so that they are appropriate to the cultural context. This study uncovers various elements of American church ministries (especially those that can be supported by technology) which church members consider important but which are poorly executed. A sample of 325 members of American churches indicated which ministries they considered most important and to what degree they believed that they were carried out well in their own church. A quadrant analysis indicated that welcoming visitors, keeping parents informed of what their children are learning, and keeping parents informed of issues that arise during church activities were aspects of ministry generally rated as very important but poorly executed.
\end{abstract}

Keywords: Church, Ministry, Evangelicalism, Outreach, Evangelism

IWe would like to thank Jonathan Hicks, Tristan Gist, Sarah Peters, and Taylor Rice of Azusa Pacific University for their help in collecting data used in this study. 


\section{Introduction}

One way church leaders try to demonstrate the love of Christ is by developing and implementing programs that meet the needs of both Christians and non-Christians. These programs may seek to meet physical, emotional, and, especially, spiritual needs. If they are successful, meeting these needs results in, among other things, Christ-honoring families, a Biblical faith, healthy community, sincere worship, and true conversions. However, the needs of Christians and non-Christians, as well as a church's ability to meet these needs, vary greatly according to context.

The needs of Christians, who are typically already committed to a local manifestation of Christ's body, vary according to both the national and local context, as well as their personal context which may be influenced by factors such as their economic situation, their family, their race, their gender, their health, their life stage, their personality, their values, and their spiritual condition. Similarly, the needs of non-Christians, who are typically not yet involved in a church, will also depend on these factors. Just as people have varying needs, they also have different expectations for how churches can respond to these needs.

The ability of churches to respond to these needs also depends on many factors. These include the resources that are available to the church, including finances, facilities, and members who are available to serve others in order to meet these needs. The ability to respond to these needs also depends on knowing what they are. Just as the Apostle Paul prayed that the Philippians' "love would abound in more and more knowledge" so that they would be "able to discern what is best" (Phil. 1:9-10, NIV), church leaders' ability to meet these needs is limited by their knowledge of what they are. The more pastoral staff members understand the needs people are experiencing, the better they are able to design programs and ministries to respond to these needs. The purpose of this study is to understand the importance placed on various ministries by American church attenders and to understand how well they believe their churches are carrying out these ministries. With this information about the strengths and weaknesses of American churches in general, church leaders can examine their specific situation to assess the degree to which these strengths and weaknesses are present in their own church. This study focuses especially on aspects of ministry which may be supported through electronic technology.

It is important for pastors and other church leaders to obtain multiple perspectives on issues that are crucial to their ministry. Because we as humans are often unaware of the information that we are missing, we suffer from blind spots that make us overconfident in our decisions (Bazerman \& Tenbrunsel, 2011). In addition, we cannot remember or process all the information that we obtain, resulting in information overload (Eppler \& Mengis, 
2004). This results in the use of heuristics, mental shortcuts that work well for responding to common problems that humans have experienced for generations but which are often ineffective when facing novel or technological problems (Dunaetz, 2010; Kahneman, 2011; Tversky \& Kahneman, 1974). One partial solution to these modern problems is crowdsourcing, enlisting the aid of multiple anonymous sources to provide relevant information that one would not be able to access otherwise (Brabham, 2008; Estellés-Arolas \& González-Ladrón-De-Guevara, 2012).

In order to gain insight into the strengths and weaknesses of present-day churches in the United States, the wisdom of lay people can be both insightful and useful. Because lay people are involved in ministries in a way that pastoral staff (especially in large churches) may not be, their insights may compensate for staff blind spots. In this study, we crowdsourced a wide range of questions to people who attend American churches, asking, "How important are various church ministries in your eyes?" and "How well does you church carry out these ministries?" The responses to these two questions are interpreted via a quadrant (or importance-performance) analysis (Ennew, Reed, \& Binks, 1993; Martilla \& James, 1977).

A quadrant analysis allows organizational leaders to understand what service users, service providers, and observers think of the programs and services provided by one or more organizations. This study focuses on the services and programs provided by American churches. The participants in the study provided information about how important they think various aspects of church ministry are and their assessment of how well they are being carried out in their own church. If the variation in the responses' average scores is greater than what one would expect by chance, then there is good evidence that the participants' experiences with churches are sufficient, and that the churches examined are sufficiently similar to one another, to determine genuine trends. For this study, the trends consist of differences in how important the various aspects of church ministry are to church attenders, as well as the perceived quality of these ministry aspects.

Each aspect of church ministries evaluated is classified into one of four categories or quadrants based on the overall average rating: 1) High Quality/High Importance, 2) Low Quality/High Importance, 3) Low Quality/Low Importance, and 4) High Quality/Low Importance. The second quadrant is the most useful for knowing how to improve ministries; it indicates the aspects of ministry which church members think are important but which are carried out poorly. This information can help the pastoral staff focus their limited resources on those aspects of ministry which are perceived to be most important and most in need of improvement. This will enable the pastoral staff to better serve the congregation by concentrating their change efforts on aspects of their programs which can respond to the greatest felt needs. 
It should be noted that such an analysis, informed by lay members, is not sufficient to determine God's will for a church. It is but one piece in the puzzle. The leading of the Holy Spirit (Van Gelder, 2007) and a biblically-informed theology of ministry priorities (Little, 2016a, 2016b) should always play a more important role in determining God's will for a church than the opinions of the attendees.

\section{Method}

In the context of a service project performed for an organization (EvangelizeUSA.com) which wished to improve a church ministry smartphone and web app (ChurchPlanner), a team of graduate students studying organizational psychology at Azusa Pacific University recruited American church attenders to participate in an online survey of their church experience. Participants indicated their beliefs concerning the importance of various aspects of their church's ministry as well as their beliefs concerning the quality of these programs.

\section{Participants}

A total of 374 participants were recruited via the social media of team members. Those who agreed with the statement "I rarely or never attend a church service" were excluded from the study as well as those who did not live in the United States, leaving 325 church attenders who provided usable data. Participants were $78.5 \%$ female, $68.9 \%$ were married or in a domestic partnership, and $76.6 \%$ were white. Their ages ranged from 20 to 85 years old, with a mean of 38.1 years. The majority of respondents lived in California (66.2\%); the remainder lived in 31 states, especially Alabama, Colorado, Michigan, and Missouri.

Participants also indicated if they were parents of children or youth in the church $(33.3 \%)$ and if they volunteered in the children's ministry or youth ministry of the church $(40.9 \%)$. If they belonged to either (or both) of these two categories, they were asked to evaluate specific aspects of their church's ministries from their point of view as a parent or as a volunteer.

\section{Measures}

All participants expressed, first, how important they believed 19 aspects of church ministry were. Then they indicated the degree to which they agreed with statements saying that these 19 aspects of church ministry were carried out well, indicating their perception 
of the quality. In addition, parents responded to statements concerning 5 aspects of the children's ministry or youth ministry. Volunteers in the children's ministry and youth ministry responded to 6 statements concerning ministry elements that were especially relevant to them. Each participant thus responded to between 19 and 30 aspects of ministry (See "Ministry Elements" in Table 1). All aspects of ministry were chosen because they are each (in some way) susceptible to being improved (or at least modernized) by the use electronic technology.

\section{Results}

Since the data for this study came from many different churches, all of which may have had different strengths and weaknesses, a one-way analysis of variance was performed on both the importance data and the performance data in order to see if there were overarching trends in differences in how participants viewed the different ministries. If there were no significant differences in the averages reported by the participants, the differences between those viewed as above average and those viewed as below average could be attributed to chance. However, both the differences in importance scores $(F(29,7109)$ $=47.64, p<.001)$ and the differences in performance scores $(F(29,7081)=22.18, p<$ $.001)$ were significant. These differences therefore justify the use of a quadrant analysis to better understand what ministry domains might be priority targets for improvement. There are clear trends indicating the importance that American church attenders accord to certain aspects of ministry and the perceived quality of their implementation.

\section{Importance of Ministries}

The average importance accorded to each of the 30 ministry aspects is shown in Table 1. The overall average of these scores is 3.07 on a 1 (least important) to 5 (most important) scale. The standard deviation ${ }^{1}$ of these scores is .40. The most important aspects of ministry were the spiritual growth of children (from the parents' perspective), the spiritual growth of children (from the volunteers' perspective), the safety of check-in procedures for children's ministries (from the volunteers' perspective), and the welcoming of guests to the church. The ministry aspects in this survey that were rated the least important were church Bible reading plans, the age of the musicians, the choice of appropriate musical keys, and the online tithing software.

\footnotetext{
${ }^{1}$ The standard deviation measures how spread out scores are. Approximately $68 \%$ of the scores in a normally distributed sample will be within one standard deviation of the mean and $95 \%$ will be within two standard deviations.
} 


\section{Table I. Labels, Quality Score, and Importance Score of the Ministry Elements}

\begin{tabular}{|c|c|c|c|}
\hline Label in Figure 1 & Ministry Element & Quality & Importance \\
\hline Age of Musicians & $\begin{array}{l}\text { A mixture of both older and younger musicians and singers } \\
\text { on the worship team }\end{array}$ & -0.73 & -1.38 \\
\hline Bible Reading Plan & A church-wide Bible reading plan & -2.76 & -1.94 \\
\hline Church Diversity & A church comprised of a racially diverse group of people. & -2.42 & -0.40 \\
\hline $\begin{array}{l}\text { Efficient Check-In } \\
\text { (Parental View) }\end{array}$ & $\begin{array}{l}\text { An efficient check-in procedure for children's ministry } \\
\text { (Parental View) }\end{array}$ & 1.43 & -0.12 \\
\hline $\begin{array}{l}\text { Efficient Check-In } \\
\text { (Volunteer View) }\end{array}$ & $\begin{array}{l}\text { An efficient check-in procedure for children's ministry } \\
\text { (Volunteer View) }\end{array}$ & 0.35 & 0.09 \\
\hline Enjoyable Songs & Singing songs I enjoy & 0.57 & -0.64 \\
\hline Feeling Welcome & Feeling welcomed when I arrive at my church & 1.18 & 0.45 \\
\hline $\begin{array}{l}\text { Growth In Faith } \\
\text { (Parental View) }\end{array}$ & $\begin{array}{l}\text { Teaching in the children's ministry and/or youth group that } \\
\text { enables a child to grow in his or her faith (Parental View) }\end{array}$ & 0.15 & 1.78 \\
\hline $\begin{array}{l}\text { Growth In Faith } \\
\text { (Volunteer View) }\end{array}$ & $\begin{array}{l}\text { Teaching in the children's ministry and/or youth group that } \\
\text { enables a child to grow in his or her faith (Volunteer View) }\end{array}$ & 0.56 & 1.62 \\
\hline $\begin{array}{l}\text { Info on Children's } \\
\text { Learning (Parental View) }\end{array}$ & $\begin{array}{l}\text { Receiving information on what my child is learning in } \\
\text { children's ministry and/or in youth group (Parental View) }\end{array}$ & -0.62 & 0.66 \\
\hline $\begin{array}{l}\text { Info on Children's } \\
\text { Learning (Volunteer } \\
\text { View) }\end{array}$ & $\begin{array}{l}\text { Parents receiving information on what their child is learning } \\
\text { in children's ministry and/or in youth group (Volunteer } \\
\text { View) }\end{array}$ & -0.35 & 0.49 \\
\hline Known by Leadership & Someone in my church leadership knows me well & -0.18 & -0.29 \\
\hline Lyric Timing & $\begin{array}{l}\text { The words on the screen corresponding to the lyrics being } \\
\text { sung }\end{array}$ & 0.85 & 0.19 \\
\hline Music Key & The key chosen for songs is neither too high nor too low & -0.79 & -1.47 \\
\hline $\begin{array}{l}\text { Online Availability of } \\
\text { Sermon }\end{array}$ & Ability to access previous sermons online & 0.31 & -0.63 \\
\hline Online Giving & Ability to donate and/or tithe online & 0.23 & -1.37 \\
\hline $\begin{array}{l}\text { Parental Notification } \\
\text { (Parental View) }\end{array}$ & $\begin{array}{l}\text { Ability to receive notifications quickly if an issue arises with } \\
\text { my child (Parental View) }\end{array}$ & -0.11 & 1.07 \\
\hline $\begin{array}{l}\text { Parental Notification } \\
\text { (Volunteer View) }\end{array}$ & $\begin{array}{l}\text { Quick notifications of parents when issues arise with their } \\
\text { child in children's ministry and/or youth group (Volunteer } \\
\text { View) }\end{array}$ & 0.53 & 1.04 \\
\hline Prepared Worship Team & A well-prepared worship team & 1.04 & 0.25 \\
\hline $\begin{array}{l}\text { Safe Check-In (Parental } \\
\text { View) }\end{array}$ & $\begin{array}{l}\text { A check-in procedure which ensures the children's safety } \\
\text { (Parental View) }\end{array}$ & 0.64 & 0.69 \\
\hline $\begin{array}{l}\text { Safe Check-In (Volunteer } \\
\text { View) }\end{array}$ & $\begin{array}{l}\text { A check-in procedure which ensures the children's safety } \\
\text { (Volunteer View) }\end{array}$ & 0.10 & 1.32 \\
\hline $\begin{array}{l}\text { Schedule Awareness of } \\
\text { Volunteers }\end{array}$ & $\begin{array}{l}\text { Knowing well in advance when I'm scheduled to volunteer } \\
\text { in children's ministry or youth group }\end{array}$ & 0.84 & 0.61 \\
\hline Small Groups & $\begin{array}{l}\text { Life groups/small groups that would be appropriate for me } \\
\text { to join }\end{array}$ & 0.61 & 0.65 \\
\hline Song Transitions & Smooth transitions between songs & 0.49 & -1.07 \\
\hline Sufficient New Songs & The introduction of new songs & -0.33 & -1.14 \\
\hline Sufficient Old Songs & The incorporation of older songs & -1.43 & -0.96 \\
\hline Volunteer Opportunities & Volunteer opportunities for me to serve & 1.41 & 0.61 \\
\hline Website & An informative church website & -0.97 & -0.43 \\
\hline Welcoming Guests & First-time guests feeling welcomed & -0.75 & 1.21 \\
\hline Worship Excitement & An exciting church service & 0.16 & -0.89 \\
\hline
\end{tabular}

Note: Quality and importance scores are standardized scores of the average ratings provided by American church attenders $(N=325)$. Cells in grey indicate ministries elements rated as above average in importance but below average in quality. 


\section{Quality of Ministries}

The average quality of the 30 ministry aspects is shown in Table 1. The overall average of these scores is 4.22 on a 1 (lowest quality) to 5 (highest quality) scale. The standard deviation of these scores is .43 . The ministry aspects that were viewed as being of the highest quality were the efficiency of the check-in procedures for children's ministries (from the parents' perspective), the availability of volunteer opportunities, the personal welcome people felt in the church, and the preparation of musicians for the worship service. The aspects of ministry which were rated to be of the poorest quality were church Bible reading plans, church diversity, a sufficient selection of older songs used in worship services, and the church website.

\section{Quadrant Analysis}

Each importance and each quality score was transformed into a $z$-score ${ }^{2}$ to easily identify which ministry aspects were judged above and below average. These scores are graphically represented in Figure 1. A quadrant analysis indicates that most of the scores fall into either the High Quality/High Importance or Low Quality/Low Importance quadrants. However, four ministry aspects are especially noteworthy because they fall into the Low Quality/High Importance quadrant: welcoming guests, parental notification systems, informing parents of what is taught in the children's and youth ministry (from the parents' point of view), and informing parents of what is taught in the children's and youth ministry (from the volunteer workers' point of view).

Welcoming Guests. Of the four ministries identified as Low Quality/High Importance, "My church does a great job at welcoming and following up with first time guests" was rated as both the most important $(z=1.21)$ and as having the lowest quality $(z$ $=-.76)$. To test if this problem area was observed especially by either older or younger church members, it was hypothesized that age was correlated with the perceived quality of the welcome and follow-up that visitors received. However, no significant correlation was found ( $r=.006, p=.911,2$ tails). Thus, it appears that church attenders of all ages believe that this is an important ministry but is lacking in quality.

\footnotetext{
${ }^{2} \mathrm{~A} z$-score is a transformation of a raw score that measures how many standard deviations away from the mean the raw score is. Negative $z$-scores indicate that the raw score is below the average and positive $z$-scores are above the mean.
} 


\title{
Figure I. Importance and Quality of Ministry Elements
}

\author{
High Importance \\ - Growth in Faith (Parental View) \\ - Growth in Faith (Volunteer View) \\ - Safe Check-In (Volunteer View) \\ Welcoming Guests • \\ Parental Notification (Parental View) • \\ Info on Children's Learning (Parental View) • \\ Info on Children's Learning (Volunteer View)• \\ Low Quality \\ -Prepared Worship Team \\ - Parental Notification (Volunteer View) \\ Safe Check-In (Parental View) \\ Small Groups • • Volunteer Opportunities \\ Schedule Awareness of Volunteers \\ - Feeling Welcome \\ \begin{tabular}{ll}
$\bullet$ Lyric Timing & High Quality \\
\hline Effcient Check-In (Volunteer view) &
\end{tabular} \\ Church Diversity \\ Website • \\ Efficient Check-In (Parental View) \\ Online Availability of Sermon \\ - $\quad$ Enjoyable Songs \\ Sufficient Old Songs • \\ - Worship Excitement \\ Sufficient New Songs• \\ - Song Transitions \\ Music Key $\bullet$ \\ - Online Giving \\ Bible Reading Plan
}

\section{Low Importance}

Note. The vertical axis indicates the importance of the ministry element and the horizontal axis indicates the quality of the ministry element as judged by American church attenders $(N=325)$.

Parental Notification Systems. The notification system used in one's church to inform parents of issues with their child was also in the quadrant of Low Quality/High Importance. The nature of such notification systems varies according to the age of a child. Since electronic parental notification systems for small children have been used in evangelical churches since at least the 1980s (e.g., illuminating large LED numbers in the sanctuary when an issue arose with a child in the nursery) and have since evolved in quality, it 
was hypothesized that parents of older children (e.g. junior high and high school students) would be less satisfied than parents of small children. To test this hypothesis, the correlation of the age of parents who had children or youth involved in the church and their satisfaction with the notification system was examined. There was a near significant negative correlation between parents' age and perceived quality of the parental notification system ( $r=-.244, p=.057,1$ tail). This means that older parents (e.g., parents of high school students) were less satisfied with the system than were younger parents (e.g., parents of children in the nursery). However, there was no significant correlation between the parents' age and perceived importance of the parental notification system ( $r=-.08, p=.58,2$ tails). This means that parents of all ages believed this to be an important aspect of ministry, but the parents of high school students felt the quality was especially low.

Informing Parents of What Children Learn. Both parents and volunteer staff were asked about parents receiving information about what their children learn in the children's ministry or youth group. Both groups agreed that this was above average in importance but below average in quality. In addition, this appears to be a problem across ministries, occurring in both children's ministries and youth groups. There was no significant correlation between the parents' perceptions of how well they are informed and the parents' age ( $r=-.099, p=.52$, two tails). Nor was there a significant correlation between the importance of being informed and the parents' age ( $r=.008, p=.96$, two tails).

\section{Outlier Influence}

The importance and quality score of a church's bible reading plan was an outlier in this study (see Figure 1). Both dimensions of the score were extremely low. To test whether this outlier influenced the results of the quadrant analysis, the data was re-analyzed without including information about the Bible reading plans. This re-analysis resulted in no changes in the quadrant Low Quality/High Importance. The same four ministry aspects remained: welcoming guests, parental notification systems, informing parents of what is taught in the children's and youth ministry (from the parents' point of view), and informing parents of what is taught in the children's and youth ministry (from the volunteer workers' point of view).

\section{Discussion}

This study has found three important areas of ministry in American churches that are perceived by lay church members to be carried out relatively poorly. First, American Christians believe that welcoming guests at the worship service is very important, but there 
is a general dissatisfaction with how churches do this. Second, parents of children involved in their church's ministries, especially the youth ministry, believe that a parental notification system is very important but they are dissatisfied with how it is carried out in their church. Third, both volunteer workers and parents of children of all ages believe it is important for parents to be informed of what their children are learning at church, but they are dissatisfied with the information that they receive. These important issues can be addressed in several ways.

Welcoming Guests. How guests are welcomed to the church was rated as one of the most important ministries of the church. This ministry is most likely considered important because first time visitors' response to their initial experience with a worship service will be one of the major factors that determines whether they will eventually become assimilated into the community or not (Searcy \& Easter, 2016; Searcy \& Henson, 2007). Assimilation into the community is an essential step to serving Christ effectively within a church. For those guests who have not yet experienced the new birth, assimilation enables them to better understand what it means to follow Christ and be part of his body, allowing them to make a more informed decision concerning whether to follow Christ or not. For believers weak in the faith and not yet integrated into the community, assimilation allows them to become more certain of their faith as they see how faith expresses itself in the lives of individuals with whom they can relate (Dunaetz, 2016).

Compared to other ministries, American Christians view this ministry as carried out poorly, especially considering its importance. Perhaps the welcoming is limited to shaking hands with an older, semi-professional greeter that the visitor has nothing in common with and whom the visitor will never interact with again (except to shake hands when entering the worship service). Perhaps the welcoming consists of a 30-second mandatory "greet your neighbor" exercise included in the worship program. Such superficial greetings may be very awkward and something that many guests would normally try to avoid. If people who are already integrated into the church feel awkward interacting with greeters and others in the prescribed manner, it is logical that they would rate this ministry poorly.

Nelson Searcy of the Journey Church in New York City argues that intentionally welcoming visitors in a culturally relevant and meaningful way is a key component of assimilation because first impressions strongly influence whether the visitors return or not (Searcy \& Easter, 2016; Searcy \& Henson, 2007). This includes managing first impressions of the church premises and assuring that the pre-worship service interactions are positive. A system of collecting information from visitors that enables follow-up is essential. This might mean that everyone in the service is strongly encouraged to fill out a connection card (either a physical card or a web-based form, perhaps in an easily downloadable app designed for the church); the example of others filling out a card or providing information on 
their phone will motivate the visitor to do the same. These connection cards should not ask for so much information that they become cumbersome. A name and email address and perhaps a cell-phone number is all that is necessary for effective follow up. However, the church must have in place a system that ensures that all first and second time visitors are contacted and provided with information that will enable them to make more permanent relationships with other people in the church through small groups or through ministry opportunities.

Food and drink provided by a team ready to meet visitors can play an important role in welcoming guests. A coffee or small snack with an attractive person (e.g., someone who is warm and socially competent) that is the same age or at the same life stage as the visitor creates a positive impression of the church and provides an atmosphere where any desired information about the church information can be provided (Sprecher, 1998; Tsui, Porter, $\&$ Egan, 2002). The presence of food or drink makes people feel at ease because food and drink consumption is a sign of safety and mutual acceptance (cf. Psalm 32:5).

The proper use of electronic technology can make greeting visitors more sincere, especially in large churches where first time visitors are likely either to know someone who attends the church or to have a mutual friend with someone already in the church. An app that would enable first time guests to find friends (or friends of friends) who are present at the same service (via Facebook, LinkedIn, Snapchat, Instagram, Twitter, etc.) could greatly assist in the assimilation process. The Facebook feature Nearby Friends (https://www.facebook.com/help/629537553762715/) could be used by visitors and regular attenders to quickly link visitors to people whom they already know during the worship service. Alternately, a more church-appropriate feature could be incorporated into an app designed specifically for the church. Besides encouraging existing, natural relationships to develop after the service (perhaps directing people to meet each other through GPS or at a small snack stand near an exit of the sanctuary), such an app could replace connection cards and provide relevant information about the worship service, the sermon, and the church.

Parental Notification Systems. Although a parental notification system, especially for youth and their parents, was deemed one of the more important aspects of a church's ministry, these systems were rated poorly by most of the parents concerned. Because youth want to become more and more independent, they are unlikely to complain to youth leaders that their parents are unhappy with a lack of live updates during their activities. Likewise, parents of youth most likely do not want to come across as helicopter parents (LeMoyne \& Buchanan, 2011). Thus, parental concern about lack of notification is likely to be only rarely vocalized, and for this reason, church leaders might be unaware of it. Nevertheless, it is an important ministry that can be improved relatively easily. 
Modern parents find themselves in a bind. They know that evening hours are the most dangerous time for youth to be out, with the highest rates of criminality and antisocial behavior (Felson \& Poulsen, 2003). In addition, the algorithms used by the news feeds of Facebook and other social media make salient the things that parents fear the most, increasing the perceived likelihood that their children will encounter danger. (Kramer, Guillory, \& Hancock, 2014; Zuckerberg et al., 2010). On the other hand, they may very well be aware of the dangers of helicopter parenting, such as a decrease in the mental health and well-being of children with over-monitoring parents (LeMoyne \& Buchanan, 2011). An effective parental notification system at church can allow parents to give age-appropriate freedom to their teenage children yet also meet their needs for reassurance concerning their children's safety.

It is likely that simple group texts to the parents of the youth would be sufficient to keep parents informed of the well-being of their children. One text during the middle of the activity (to let parents know that their child is at the activity and no accidents have occurred) and one text at the end (to inform parents that the activity is over) would most likely satisfy the needs of parents to be informed of the status of their children. If some accident did befall a child, this same database of phone numbers could be used to easily notify the child's parents of the issue.

Alternately, the youth staff can create a specific Twitter account directed at parents of the youth attending the church. During youth activities, regular tweets can describe the progression of the activity, with a special focus on safety. With Twitter, no database of parental phone numbers needs to be managed, but it is likely that many parents will repeatedly need instructions on how to use Twitter and how to follow the appropriate account.

Informing Parents of Curriculum. Both parents and volunteer workers agreed that informing parents of the material covered in the children's and youth ministry was important but poorly carried out. The underlying assumption is that the material covered in church programs will have a greater effect if parents can interact with the child or teen concerning the curriculum. This is certainly true in the general education system (Desforges \& Abouchaar, 2003; Jeynes, 2005), and there is no reason to doubt that it would be equally true in churches.

Traditional approaches to encouraging parental involvement (apart from recruiting parents as volunteers) include giving children handouts or memory verses to take home in order to potentially share with their parents. However, electronic communication, especially email, may make it more likely that the parent receives relevant information in a timely and useful form. Such information, perhaps sent twice weekly on Monday and Saturday, not only ensures that the parents are kept informed but also serves as a reminder to bring their child to church that week. The utility of this information could be increased by 
providing twice-a-year training opportunities for parents that are appropriate to the sociodemographic context of the community. The purpose of this training would be to help parents better raise their children, including how to integrate material from the children's program into a child's home life. Such training sessions for parents could also be integrated into other outreach ministries within the church.

Limitations and Future Research. Several limitations to this study should be noted. First, this study has found certain ministry strengths and weaknesses of American churches, but it has examined relatively few areas of ministry, paying special attention to those which might easily be improved via technology. It has not examined many important ministries such as teaching and preaching, small groups, or worship. These ministries, of course, are likely to have far more impact on people than some of the ministry aspects considered in this study. Future quadrant analysis studies of church ministries should examine a broader range of ministries.

A second limitation is that this study looks at American churches as a whole, not as individual churches. Although it provides information about how American church attenders typically view specific ministries, it provides no information about the ministries of any specific church. This is a useful starting point for individual churches to reflect upon the ministries highlighted in this study which need improvement, but it in no way implies that any of these tendencies are true in a given church. Because quadrant analyses are simple and straightforward, individual churches could carry out similar studies, limiting their sample to people who attend the church being studied. Such a study would provide more specific and accurate information on which ministries people in the church think are important and which need improvement.

Conclusion. Designing church programs that meet the needs of either Christians or non-Christians is a manifestation of Christ's love. This study has examined what American church attenders believe is important in their churches and what they believe to be carried out well. The analysis of the data found three areas of ministry that are generally considered very important but poorly implemented: welcoming visitors, parental notification systems (especially for the youth ministry), and informing parents of what is being taught in the children's and youth ministries. If church leaders can improve these three important ministries, they will more effectively carry out Christ's call to love one another (John 13:34) and to make disciples of all the earth (Matt. 28:18-19). 


\section{References}

Bazerman, M. H., \& Tenbrunsel, A. E. (2011). Blind spots: Why we fail to do what's right and what to do about it. Princeton, NJ: Princeton University Press.

Brabham, D. C. (2008). Crowdsourcing as a model for problem solving: An introduction and cases. Convergence: The International Journal of Research into New Media Technologies, 14, 75-90.

Desforges, C., \& Abouchaar, A. (2003). The impact of parental involvement, parental support and family education on pupil achievement and adjustment: A literature review. Nottingham, UK: DFES Publications.

Dunaetz, D. R. (2010). Organizational justice: Perceptions of being treated fairly. In D. Baker \& D. Hayward (Eds.), Serving Jesus with integrity: Ethics and accountability in mission (pp. 197-221). Pasadena, CA: William Carey Library.

Dunaetz, D. R. (2016). Missio-logoi and faith: Factors that influence attitude certainty. Missiology: An International Review, 44, 66-77.

Ennew, C. T., Reed, G. V., \& Binks, M. R. (1993). Importance-performance analysis and the measurement of service quality. European Journal of Marketing, 27, 59-70.

Eppler, M. J., \& Mengis, J. (2004). The concept of information overload: A review of literature from organization science, accounting, marketing, mis, and related disciplines. The Information Society: An International Journal, 20, 325-344.

Estellés-Arolas, E., \& González-Ladrón-De-Guevara, F. (2012). Towards an integrated crowdsourcing definition. Journal of Information Science, 38, 189-200.

Felson, M., \& Poulsen, E. (2003). Simple indicators of crime by time of day. International Journal of Forecasting, 19, 595-601.

Jeynes, W. H. (2005). A meta-analysis of the relation of parental involvement to urban elementary school student academic achievement. Urban Education, 40, 237-269.

Kahneman, D. (2011). Thinking, fast and slow. New York, NY: Farrar, Straus and Giroux.

Kramer, A. D., Guillory, J. E., \& Hancock, J. T. (2014). Experimental evidence of massivescale emotional contagion through social networks. Proceedings of the National Academy of Sciences, 111, 8788-8790.

LeMoyne, T., \& Buchanan, T. (2011). Does "hovering" matter? Helicopter parenting and its effect on well-being. Sociological Spectrum, 31, 399-418.

Little, C. R. (2016a). The case for prioritism: Part 1. The Great Commission Research Journal, 7, 139-162.

Little, C. R. (2016b). The case for prioritism: Part 2. The Great Commission Research Journal, 8, 6-20. 
Martilla, J. A., \& James, J. C. (1977). Importance-performance analysis. The Journal of Marketing, 41, 77-79.

Searcy, N., \& Easter, M. C. (2016). How donald mcgavran has impacted one urban church plant and indirectly influenced thousands of other churches: An analysis of the journey church of the city. Great Commission Research Journal, 8, 21-31.

Searcy, N., \& Henson, J. (2007). Fusion: Turning first-time guests into fully-engaged members of your church. Grand Rapids, MI: Baker Books.

Sprecher, S. (1998). Insiders' perspectives on reasons for attraction to a close other. Social Psychology Quarterly, 61, 287-300.

Tsui, A. S., Porter, L. W., \& Egan, T. D. (2002). When both similarities and dissimilarities matter: Extending the concept of relational demography. Human Relations, 55, 899929.

Tversky, A., \& Kahneman, D. (1974). Judgment under uncertainty: Heuristics and biases. Science, $185,1124-1131$.

Van Gelder, C. (2007). The ministry of the missional church: A community led by the Spirit: Baker Books.

Zuckerberg, M., Sanghvi, R., Bosworth, A., Cox, C., Sittig, A., Hughes, C., . . Corson, D. (2010). Dynamically providing a news feed about a user of a social network. U.S. Patent no. 7,669,123. Washington, DC: U.S. Patent and Trademark Office.

David R. Dunaetz (ddunaetz@apu.edu) is Assistant Professor of Leadership and Organizational Psychology at Azusa Pacific University. He was a church planter in France for 17 years with WorldVenture where he planted two churches and helped several others move beyond missionary dependence. He is a graduate of Harvey Mudd College (B.S.), the University of Southern California (M.S.E.E.), Denver Seminary (M.Div.), University of Paris La Sorbonne (Magistère), Fuller Seminary (Th.M.), and Claremont Graduate University (M.A., Ph.D.).

Joshua McGowan (jdmcgowan@apu.edu) is the Assistant Director of Recruitment for Graduate and Professional Admissions at Azusa Pacific University. He has a passion for the worship arts, especially focusing on the development of congregational worship and effective volunteer functioning. He is a graduate of Azusa Pacific University (B.A. in Music and M.S. in Organizational Psychology). 